\title{
Teacher Quality Work Life in Aceh, Indonesia and Malaysia Northern Peninsula: A Cross-Nation Study
}

\author{
Nurmawati \\ State Institute of Islamic Studies (IAIN) Langsa, Acheh-Indonesia
}

\begin{abstract}
This study investigated about Teacher Quality Work Life (TQWL) or teacher working performance within cross-nation between Malaysia and Indonesia. The portion in teacher quality work life has four dimensions, i.e., psychology-need, social-need, political-need, and economy-need. The research method applied survey cross-sectional forms. The cross-sectional study involved the samples - teachers - to be compared through different applied culture dimension of one time. The population of the study encompassed the primary teacher-state of Malaysia and the elementary teacher of Indonesia. The study applied quota sampling to select 400 teachers of elementary school for both Malaysia and Indonesia. The study applied One-way ANOVA inference statistical to analyze the comparison of teacher quality work life in primary school teachers. The four dimensions of Teacher Quality Work Life (TQWL) shared different features. For psychology-need, the Malaysian teacher $(\mathrm{M}=0.50$ logits, $\mathrm{SP}=0.25)$ was lower than the Indonesian teacher $(\mathrm{M}=1.14$ logits, $\mathrm{SP}=0.50)$. For social-need, the Malaysian teacher $(\mathrm{M}=0.61$ logits, $\mathrm{SP}=0.30)$ was also lower than the Indonesian teacher $(\mathrm{M}=0.75$ logits, $\mathrm{SP}=0.48)$. For political-need, the Malaysian teacher $(\mathrm{M}=0.82$ logits, $\mathrm{SP}=0.36)$ was also lower than the Indonesian $(\mathrm{M}=-0.09$ logits, $\mathrm{SP}=0.62)$. For economy-need, the Malaysian teacher $(\mathrm{M}=-0.71$ logits, $\mathrm{SP}=0.63)$ was also lower than the Indonesian teacher $(\mathrm{M}=-0.09$ logits, $\mathrm{SP}=0.62)$. The result of ANOVA (Analysis of Variance) analysis indicated that the orientation of culture influences samples response for these two countries-states, Malaysia and Indonesia. Thus, itraised the three-main necessity dimensions, i.e., psychology, society, and politics, than, economy was erased at ease.
\end{abstract}

Keywords: teacher quality work life, cross-nation

\section{Introduction}

Teachers are individuals who are believed to have a significant impact in the classroom and play an important role in educating the younger generation (Nordin, 2010). Teachers are key factors in determining the quality of teaching and learning that can directly improve the quality of education of a nation. Teachers are in control of the educational process in the classroom to achieve educational goals that are set before the process of learning takes place. However, the demands of work-life teachers require the government and ministry of education attention. Thus, it might affect the teachers' job commitment and satisfaction and negatively degrade the quality of work-life.

There are several problems in primary school and the research object, which affect the learning process.

Nurmawati, M.Pd, Ph.D., lecturer in Faculty of Education and Teachers Training, State Institute of Islamic Studies (IAIN) Langsa, Acheh-Indonesia. 
They are the intolerant schools' facilities; the students are crowded for one class; the staffs' quality are poor; the teachers' morale is low; facilities vandalism and the materials are not considered adequate; the community relation is weak; the disciplinary is high; the violence occurs for students, teachers, parents, and the ineffective managements leadership at school (Gowrie, 2014).

A good teacher quality worklife affects work performance and effectiveness in the delivery of excellent human-model based on the aspirations of state. However, the study is led to review and assess the quality of work-life for cross-country school very rarely done in the context of education. The study aims to examine the similarities and differences in the quality of work life of cross-country teachers in Malaysia and Indonesia. That the group differences border these countries which have similar but different cultures makes this study unique and significant to study the similarities and differences between teachers' perception of the teacher quality worklife for a cross-comparison between countries in terms of cultural orientation, but almost the same pattern of administration.

\section{Literature Review}

\section{The Concept of Teachers Quality Work Life (TQWL)}

The teacher is one of the important human resources. Essentially, the success of educational system depends on the quality of teachers. Then, the strength and quality of education system repose on the teachers' work-life determination for their institution. The teacher work-life is career-life in education. Moreover, the teacher spends 12 work-hours for a day in making up a third of their life portions. Therefore, their work should be in satisfaction and peace. These are the efforts to improve the quality of working life. Therefore, those efforts become characteristic of the history of human civilization. The quality of life of the work is related to the nature of the education organization and climate changes the organization that serves to improve the quality of life of the work of the teacher (Manju, 2014).

The quality of professional teacher-training depends entirely on the teachers themselves, who are individually responsible for the implementation of the responsibility to teach educational curriculum and carry out activities in co-curricular activities in or outside the classroom (Tsui \& CHENG, 1999). Hence, it is not surprising that professional teachers are now receiving extreme pressure from educational beneficiaries; whether from parents, guardians, the curriculum initiators, interest groups, and governments (Barker, 2001). Because of those pressures, the teachers have a role and responsibility to provide and prepare the students as human resources. The situation is exacerbated by the enthusiasm demand from parents in forming the education and testing excellences of the students as well as the national education system that is more inclined towards "exam-oriented".

Work experience in positive and negative for teachers has so far contributed to the quality of life of the teachers working in schools (Gowrie, 2014; Been, 1994). Then the negative factors have weakly affected the quality of work life of teachers as relations between teachers and staff, teachers and ministry, and demands of parents. For teachers, insecure working environments and incompetents' institution leadership diminish morale and work-life satisfaction. Conversely, a positive teaching experience as professional in interactions, feedbacks, leadership supports, roles clarity, participations in decision-making, policy affective discipline, and autonomy will lead to a better work-life spirit. A pleasant working environment and regular compactness staff, adequacy of resources, interaction between schools and communities, the results of participation, relationship of student-teacher, and leadership support are the significant factors that affect the quality of work life of teachers 
(Gowrie, 2014).

The teachers quality worklife is a significant element in ensuring the needs of teachers as workers and individuals met by the school organization. The good teacher quality work-life is responsible in providing the motivation and job satisfaction of teachers in schools versus extrinsic and intrinsic rewards (Mohd, 1996; Mohd \& Roodzi, 1997). It is essentially worked for teachers to get and have it in school. Hence, it will affect teachers' attitudes, performances, and productivities toward work as the school effectiveness in whole sectors (Nordin, 2010).

Nor Azmawati, Nordin, Mohammad, and Hazri (2010) have defined the teacher quality as the ability of school organization and the work environment in schools, which should be encouraged and met for the needs of psychological, social, political, and economic teachers by providing opportunities to progress and develop their potential, promotion, rewards, and job security.

\section{Dimensions of Teachers Quality of Work Life (TQWL)}

Based on the findings of an analysis of the theory and the components of the quality of life this work, Nordin et al. (2010) have grouped the quality of life of teachers' work, namely: psychological needs, social needs, the need for politics, and economic needs. The needs of teachers in each dimension are presented in Table 1.

Table 1

Dimensional Measuring Instruments Teacher Quality Work Life

\begin{tabular}{|l|l|}
\hline Dimensions & Descriptions \\
\hline Psychological needs & $\begin{array}{l}\text { What extent the internal state school organization can meet the psychological needs of teachers, } \\
\text { namely: the essence of yourself, respect you and honor yourself. }\end{array}$ \\
\hline Social needs & $\begin{array}{l}\text { The extent to which the internal state school organization can meet social needs of teachers, } \\
\text { namely: the relationship colleagues and professional teaching. }\end{array}$ \\
\hline Political needs & $\begin{array}{l}\text { Extent to which the internal state school organizations can satisfy the political needs of teachers, } \\
\text { namely: democracy and autonomy, trust and honesty colleagues and justice. }\end{array}$ \\
\hline Economy needs & $\begin{array}{l}\text { The extent to which the internal state school organization can meet the economic needs of teachers, } \\
\text { namely the need themselves. }\end{array}$ \\
\hline
\end{tabular}

(Source: Nordin et al., 2010, p. 26)

\section{The Psychological Needs}

The dimensional needs of psychology show to measure the extent to which school organization can meet the needs of teachers measured in terms of psychology, which directly has an impact on the internal self-teacher inherent in the behavior of teachers within the school. Psychological needs are measured by three sub-dimensional needs, namely: personal judgments, respects, and proudness. The personal judgment is personal development to reach maximum self-actualization. Personal judgment, according to Maslow's self-perfection, is about personality grade in the hierarchy of human needs (Azizi \& Jaafar, 2006). It is an approach to investigate self-personality as a strong and positive individual, who is able to conduct many possibility activities. On the contrary, the negative individuals feel discouraged and tend to not believe in themselves. It covers on the inner potential owning characteristics. The teacher comments on personal judgment taking on personal awareness and self-cautiousness abosut the strength and weakness of being educator. This self-awareness comes from relationship interaction, socializations, and interaction between teachers. The next sub dimension is personal respect. Personal respect is the attention of personal society getter, achievements, skills, and capability, which raised personality brand. The necessity of personal brand or dignity 
will play an important role in pushing a person work determinately. On the other hand, this necessity is the necessity to be honored and respected. The last measured sub dimension is personal proudness. It is a teacher's feeling about their self-esteems for being an ideal person.

\section{The Social Needs}

The social dimension indicates the capability of school in providing teachers' necessity about social sectors, i.e., co-worker relationship and teacher profession. The good co-worker relationship influences the school's teacher environment. The next sub dimension is the advantages of teacher profession. The competent teacher should acquire adequate knowledge, which leads to maximizing their ability for classroom teaching-learning mapping. The teacher who is able to adapt quickly to national education policy should be given space to keep them move forward for their qualification. The professional characteristic is well-known as important to be effective teaching-learning. The professionals provide strength, trust, and capability for making decision on actual statement and action for teacher daily services.

\section{The Political Needs}

The political dimension indicates the capability of school in providing teachers' necessity about political sectors, i.e., democracy, autonomy, trust, honesty, and justness. As institution, the schools will never neglect the constructive inner elements for the existence of political at school. The school experiences of political process as depicted-power, delegation, and responsibility of teacher in the school environment. On the other hand, democracy, autonomy, trust, honesty, and justness on personal matter are majorly important to be measured. It happened because the school is social entity with member, who has member, such as national cooperatives, promotions, salary, and social mobility. This phenomenon takes competition between members for teachers, who have personal objective to be fulfilled as individual. When inner political sector is taking politic behavioral as stated on inner environment on school institution, it occurred (Nor Azmawati et al., 2010).

\section{The Economic Needs}

The economical dimension indicates the capability of school in providing teachers' necessity about economic sectors, i.e., personal economic necessity. The economy necessity is an important matter for teachers in daily live as positive support about the profession itself. Economic sectors, what is meant on this study, is personal income, that owned by the teacher and its implication to fulfill primary and secondary necessity (Sirgy, Efraty, Siegel, \& Lee, 2001). Economics is meant here as the teachers' income that is received by teachers every month can benefit themselves both weeks to the primary requirement or secondary.

\section{Cross Country Studies}

Cross country study is the cross-sectional study that running to two or more countries to compare culture of any country surveyed. Each country has a different and unique culture to other country. Culture or identity is a symbol of a country. Culture is a social construct that has an impact on a group or an individual. The impact can be a pattern of behavior, the level of economic and technological level. To conceptualize culture, we must start from the definition of the culture of its own which includes ideas about how culture: How culture is carried out, why culture is important, how we can discover the culture, and how we can deliver a picture of culture as a social idea in oral form.

The definition of culture in terms of management research, according to Kempton, Boster, and Hartley (1995), suggested that cultural patterns shape the issues that people see as something critical, affecting their 
perceptions and their response. Culture is a system of values and beliefs that affect what they believe is acceptable and unacceptable. People of one culture with its own share the same values and thus interpret things the way they are basically identical. While in the research design, the people from different cultures tend to interpret things in a different way.

Hofstede (1991) addressed the concept of culture in particular from a country or a community perspective, he defined culture as the pattern of thought, feeling, and action based on programming collective the mind that distinguishes the members of one group or category of people from another. Culture is a system of shared assumptions, beliefs, values, and behavior in a given group, community, or country (Pettigrew, 1979; Schwartz \& Davis, 1981; Schein, 1992; Yin Cheong, 2000). So it concluded that culture is as a social construction that distinguishes one group to another sectional both in terms of meaning and behavioral and technological progress.

In a cross-country study, it was conducted in two countries with different society and culture, namely: Malaysia and Indonesia. A cross-country study was conducted to compare the relationship between variables possibility in the Teachers Quality Work Life (TQWL). Then it suggested how the variables work differently in the context of different countries and cultures. The study of cross country and a language are used to compare a wide scope of opinions, attitudes, values, and skills among groups of different cultures (Kankaras \& Moors, 2010). Moreover, the measurements were made in cross-similarities and differences for Malaysian and Indonesian teachers.

\section{The Research Method}

The study also adapted the survey methods (survey) which in particular is known as the "cross-sectional" to obtain data from a sample selected in the study population. According to De Vaus (2001), the "cross-sectional" has three distinctive features, i.e., (1) Data are collected at a specific time; (2) the data are collected and analyzed depending on the differences that existed at that time; and (3) a group is founded by the differences that exist. In this study, the difference arose from the gender (Male and Female) of the teacher and also differences in the status of teachers in work.

\section{Population and Sample Selection Technique}

The study taking population across the country between Malaysia and Indonesia involves a comparison sample of teachers from different populations of the country. Thus, the selection of the sample of this study confirmed similar extent possible between the two countries. The population in this study consists of teachers who teach in primary (elementary schools) in the state of Penang, Kedah, and Perak (Malaysia) and in primary schools Aceh province (Indonesia), namely: Banda Aceh, Pidie Jaya, Aceh Tamiang, and Kota Langsa; samples are equivalent because the teachers were selected as samples that teach in primary school (or in Indonesia called elementary school).

The technique of sampling used in the study of cross-country involves sampling technique stratification (stratified sampling). Sampling techniques are in some cases necessary to ensure that the sample of countries varies to represent particular characteristics such as income, level of education, age, race, family or single-parent household or a single parent, or a business than people (Craig \& Douglas, 2005). It is very important for the same segment to be targeted to different countries. A random sample was taken from each group or stratum of the population of interest.

In Malaysia, the sampling has been selected among the teachers who teach in primary schools in three states in northern Peninsular Malaysia, namely Penang, Kedah, and Perak. The overall population of primary 
school teachers in Penang, Kedah, and Perak with the number of samples taken from Malaysia stood at 400 people. In Indonesia, particularly in Aceh Province to the districts, the study took the samples by random. There are 5 (five) city districts selected to be samples and they are Aceh Tamiang, Langsa, Bireuen, Pidie Jaya, and Kota Banda Aceh. The study selected 400 teachers who taught at elementary schools.

\section{The Research Instruments}

The study applied questioner as instrument to collect the data. The questionnaire of teacher quality worklife is constructed by Nordin et al. (2010). It aims to measure the Teachers Quality Work Life and contains four main dimensions, namely: (a) psychological needs; (b) social needs; (c) political needs; and (d) the needs of the economy. The original questionnaire contains 42 items. Each item or statement in this questionnaire follows with six possible answers using a Likert scale ranging from (0) strongly disagree (STS), (1) disagree (TS), (2) somewhat disagree (SKS), (3) agree (S), (4) strongly agree (SS), and (5) very strongly agree (SSS). Detailed parts of the questionnaire are as follows:

Section A: Demographics

Section B: Psychologycal Needs (31 items)

Part C: Social Needs (23 items)

Part D: Political Needs (23 items)

Part E: Economy Needs (six items)

\section{The Data Analysis}

The Measurement between similarities and differences of the Teachers Quality Work Life of between two groups with different countries carried out against the background main dimensional needs: the psychological, social, political, and economic. This section explains the similarities and differences between groups of countries are descriptive of the main dimensions of Teachers Quality Work Life. The Analysis ANOVA (one-way analysis of variance) using SPSS version 21.0 is to obtain mean scores in units logits for each group of states for each dimension in Table 2 and Figure 1.

Table 2 shows that the four dimensions of the primary needs of TQWL in the country vary. On the psychological needs of teachers in Malaysia $(M=0.50$ logits, $S D=0.25)$, it is lower than for teachers in Indonesia $(M=1.14$ logits, $S D=0.50)$. On the social needs of teachers in Malaysia $(M=0.61 \operatorname{logits}, S D=$ $0.30)$, it is lower than for teachers in Indonesia $(M=0.75$ logits, $S D=0.48)$. On the political needs of teachers in Malaysia $(M=0.82$ logits, $S D=0.36)$, it is lower than for teachers in Indonesia $(M=1.38$ logits, $S D=0.84)$. On the economic needs of teachers in Malaysia $(M=-0.71$ logits, $S D=0.63)$, it is lower than for teachers in Indonesia $(M=-0.09$ logits, $S D=0.62)$. Generally there are differences in the perception of teachers in Malaysia and Indonesia on the Quality of Work Life themselves.

\section{Table 2}

Analysis of Mean Scores Dimension Needs of TQWL Between Malaysia and Indonesia

\begin{tabular}{lllll}
\hline Dimension & \multicolumn{2}{c}{ Malaysia } & Indonesia \\
\cline { 2 - 5 } & Mean & SD & Mean & 0.50 \\
\hline Psychological needs & 0.50 & 0.25 & 1.14 & 0.48 \\
Social needs & 0.61 & 0.30 & 0.75 & 0.84 \\
Political needs & 0.82 & 0.36 & 1.38 & 0.62 \\
Economic needs & -0.71 & 0.63 & -0.09 & \\
\hline
\end{tabular}


The Chart 1 listed the obvious differences between teachers in Malaysia and Indonesia on the quality of their work life based on four key dimensions of Teachers Quality Work Life, namely: the need for psychology, social, political, and economy. The difference is visible from both countries which are very far, the perception of teachers in Indonesia on the quality of their lives will be better than teachers in Malaysia.

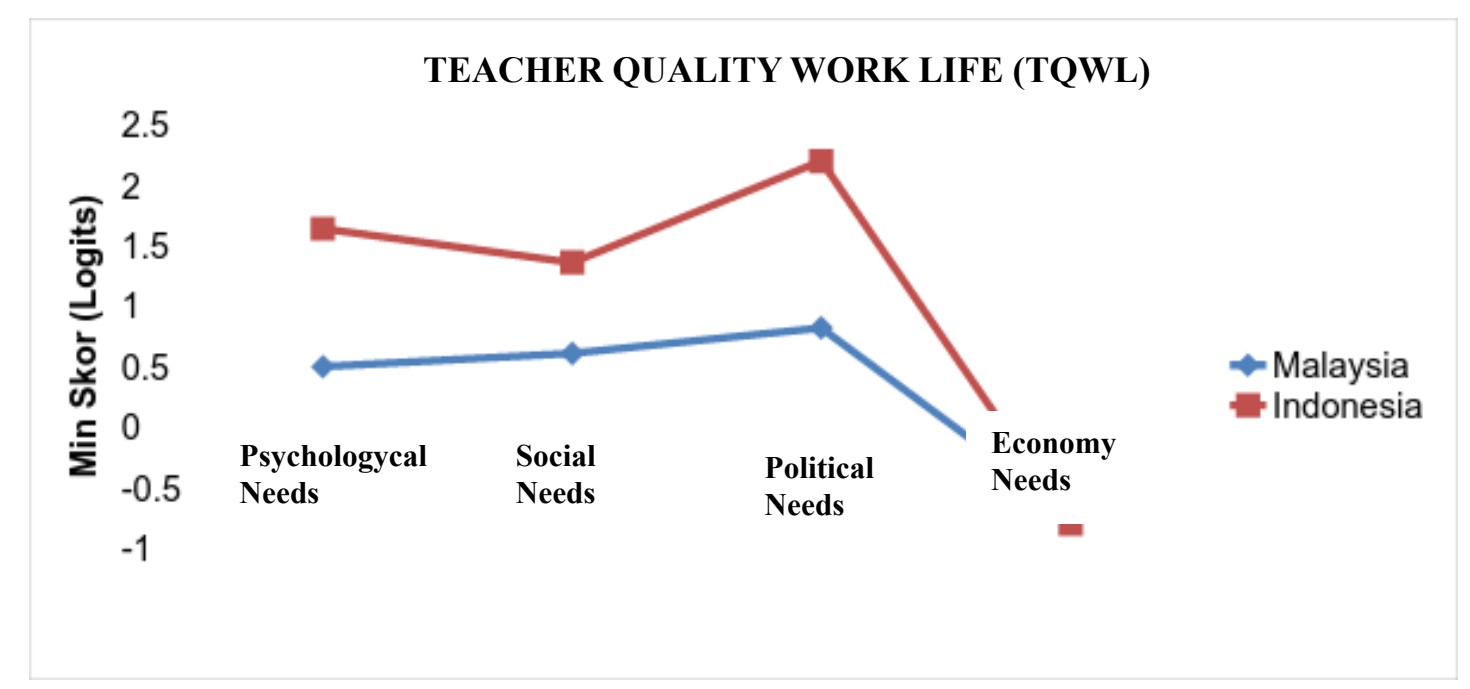

Figure 1. Comparison of four-dimensional needs of the TQWL between two groups of countries.

\section{Research Finding}

The Teachers Quality Work Life is one aspect which is rarely given attention in the research field of special education in Indonesia and there is no instrument to measure it. Various definitions and dimensions of Teachers Quality Work Life submitted in international studies and it depends on the context and culture or the countries in which it operates educational organizations. This study has successfully measured the equity instruments. Teachers Quality Work Life was built by Nordin et al. (2010) across Malaysia and Indonesia. The conceptualization of the construct of Teachers Quality Work Life in the context of a multicultural society consists of four main dimensions, namely: (1) the psychological needs; (2) social needs; (3) political needs; and (4) economic needs. Each requirement, in addition to the economic needs, has several sub dimensions. Psychological needs: personal judgment, self-respect, self-respect, and self-pride. Social needs: contact colleagues and advantages of the teaching profession. Political needs: democracy and autonomy, trust and honesty colleagues, and justice.

Dimensions requirement can describe the Teachers Quality Work Life across the country between Malaysia and Indonesia which shows that there is no difference in Teachers Quality Work Life (TQWL), which is significant in the dimension requirements for psychology, society, and politics. Thus it can be said that the profile of teacher quality of life in Malaysia and Indonesia as the third requirement of the Teachers Quality Work Life Malaysia and Indonesia is one country that has a lot in common borders. From this point of history, there are people of Indonesian descent Malaysia so that the social and psychological conditions are similar to those in Indonesia. Although, the two countries have borders, Malaysia and Indonesia have political differences caused by different systems of government; Malaysia runs government systems, while Indonesia is running the parliamentary system. Not only that, the comparison of the country and much of the population will also affect 
the internal politics of the country. There is one thing that is similar between Malaysia and Indonesia in the education of political decisions in the field of education centering on the government rather than the absolute leadership of the country. Up of the results of this investigation also showed that the profile of the political requirements of Teachers Quality Work Life between Malaysia and Indonesia is the same.

In contrast to the economic dimension needs, it is found that there is a difference in Teachers Quality Work Lifes (TQWL) which is significant. This can be caused by different national economic systems between Malaysia and Indonesia. Especially in Indonesia, particularly Aceh is a new state 10 years ago in spite of the governments war with the government precisely in 2006, so that the economy slumped from Malaysia. This is indicated by the slow economic turnaround and a high level of economic inflation in Aceh. For the economic needs, there are many teachers who are stressed by the demands of work and benefits that are not commensurate with the work. This led teachers in Aceh to find a side job outside their work as a teacher to meet the needs of everyday family.

\section{References}

Azizi, Y., \& Jaafar, S. L. (2006). Development of self concept. Pahang: PTS Publising Sdn Bhd.

Craig, C. S., Greene, W. H., \& Douglas, S. P. (2005). Culture matters: Consumer acceptance of US films in foreign markets. Journal of International Marketing, 14(4), 80-103.

De Vaus, D. (2001). Research design in social research. London: Sage.

Gowrie, G. (2014). Perceived factors that influence teachers' quality of work life in primary school in one education district in Trinidad and Tobago. International Journal of Humanities Social and Educations, 1(10), 101-113.

Hofstede, G. (1991). Cultures and organizations: Software of the mind. London, UK: McGraw-Hill.

Kankaras, M., \& Moors, G. (2010). Researching measurement equivalence in cross-cultural studies. PSIHOLOGIJA, 43(2), 121-136.

Kempton, W., Boster, J., \& Hartley, J. (1995). Environmental values in American culture. Cambridge, MA: MIT Press.

Manju, N. (2014). Quality of work life: Perseption of school teachers. International Journal of Education and Psychological Research (IJEPR), 3(2), 77-80.

Morin, E. M., \& Morin, W. (2004). Quality of work life and firm performance at Canada. In V. R. P. Kashyap and E. Mradula (Eds.), Quality of work life: Introduction and perspectives (pp. 86-96). Hyderabad, India: ICFAI University Press.

Nor Azmawati, A. R., Nordin, A. R., Mohammad, Z. A., \& Hazri, J. (2010). Politik Dalaman Sekolahdan Impaknya Kepada Sekolah: Satu Penerokaa (Internal politics and its impact on school education: An exploration). Jurnal Pengurusan Pendidikan, 10(1), 79-86.

Nordin, A. R., Hazri, J., Mohd, O. H., \& Mohammad, Z. A. (2010). Kualiti Kehidupan Kerja Guru Sekolah Rendah: Studi perbandingan etnik (Teacher quality work life of primary school: Comparative study of etnic): Geran penyelidikan universiti (University research grant). Pulau Pinang (akanditerbitkan): Universiti Sains Malaysia.

Sirgy, M., Efraty, D., Siegel, P., \& Lee, D. J. (2001). A new measure of quality of working life (QWL) based on need satisfaction and spillover theories. Social Indicators Research, 55(3), 241-302.

Tsui, K., \& CHENG, Y. (1999). School organizational health and teacher commitment: A contingency study with multi-level analysis. Educational Research and Evaluation, 5(3), 249-268.

Yin Cheong, C. (2000). Cultural factors in educational effectiveness: A framework for comparative research. Journal School Leadership and Management, 20(2), 207-225. 